\title{
HIGH TUMOR STROMA PROPORTION IS A WORSE PROGNOSTIC FACTOR IN COLORECTAL CANCER
}

\author{
Josipa Flam ${ }^{1,2}$, Damir Gugić ${ }^{1,2}$, Mirta Benšić ${ }^{3}$, Snježana Tomić ${ }^{4}$ and Jasmina Rajc ${ }^{2,5}$ \\ ${ }^{1}$ Department of Oncology, Osijek University Hospital Center; \\ ${ }^{2}$ School of Medicine, ${ }^{3}$ Department of Mathematics, Josip Juraj Strossmayer University, Osijek; \\ ${ }^{4}$ Clinical Department of Pathology, Split University Hospital Center, Split; \\ ${ }^{5}$ Clinical Department of Pathology, Osijek University Hospital Center, Osijek, Croatia
}

\begin{abstract}
SUMMARY - High stroma proportion appears to be a very important prognostic factor in esophageal and breast cancer. Previous researches have shown that it might have a similar effect on colorectal cancer. The aim of this study was to determine whether tumor stroma proportion influenced patient survival. This retrospective study included 236 patients with colorectal cancer having undergone surgery in 2006 and 2007 at Osijek University Hospital Center. Location with the highest stroma proportion at the site of deepest tumor invasion was determined. Patients were divided into the groups with high stroma proportion $(>50 \%)$ and low stroma proportion $(\leq 50 \%)$. Stroma proportion showed a statistically significant correlation with tumor stage. Kaplan-Meier survival curves yielded a statistically significant difference in patient overall survival (Cox ph model $\mathrm{p}=0.016$ ) and progressionfree survival (Cox ph model, $\mathrm{p}=0.0188$ ) according to stroma proportion. Study results showed a statistically significantly shorter overall survival and progression-free survival in patients with high stroma proportion.
\end{abstract}

Key words: Colorectal neoplasms; Stromal cells; Survival; Disease-free survival; Disease progression; Prognosis

\section{Introduction}

Colorectal cancer is a huge health issue. Unfortunately, the incidence and mortality of colorectal cancer have been growing in Croatia as opposed to developed countries $^{1,2}$. Postoperative patient treatment poses a special kind of problem ${ }^{3}$. Patients with disease stage I are not indicated any additional therapy after the surgery ${ }^{4}$. Patients with disease stage III are indicated additional chemotherapy after the surgery ${ }^{5}$. Patients with disease stage II present a special problem; about $25 \%$ of these patients have disease recurrence within 5

Correspondence to: Josipa Flam, MD, Clinical Department of Oncology, Osijek University Hospital Center, J. Huttlera 4, HR-31000 Osijek, Croatia

E-mail: jflam@mefos.hr

Received December 14, 2016, accepted January 16, 2017 years ${ }^{6}$. The influence of additional chemotherapy on patients with disease stage II has been the basis for several clinical trials. Results of a meta-analysis of 5 trials have shown patients with disease stage III to benefit most from additional chemotherapy ${ }^{6-8}$. However, new results of 12 controlled clinical studies from 1988 to 2010 have shown significant benefit of additional chemotherapy in patients with disease stage $\mathrm{II}^{9}$.

On the other hand, the Quasar Collaborative Group study ${ }^{6}$ has shown little benefit of chemotherapy compared to no chemotherapy in patients with disease stage II. The benefit was about $3.6 \%$. This percentage is below the accepted level of 5\% and therefore chemotherapy for the entire stage II group is not advised.

Numerous studies have shown which parameters mean worse prognosis for patients with colorectal cancer. These parameters include evaluation of less than 

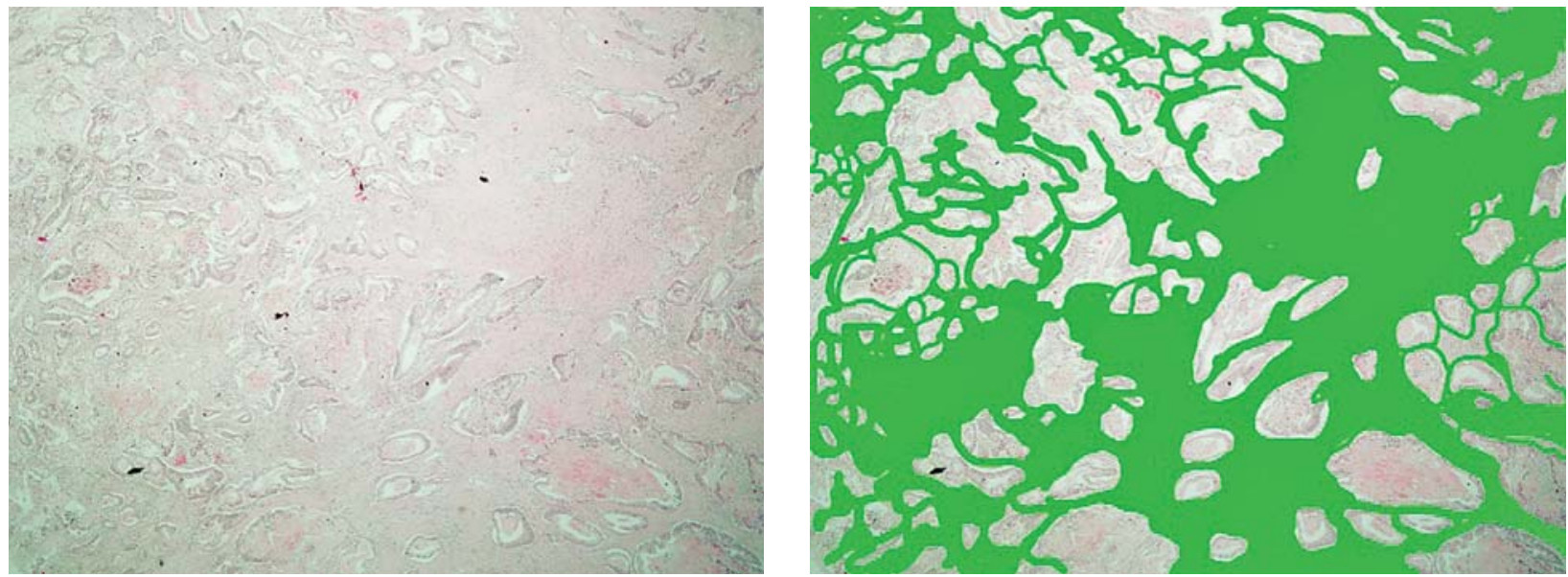

Fig. 1. Determination of stroma proportion using computer Adobe Photoshop CS2 when tumor is covering whole photo.
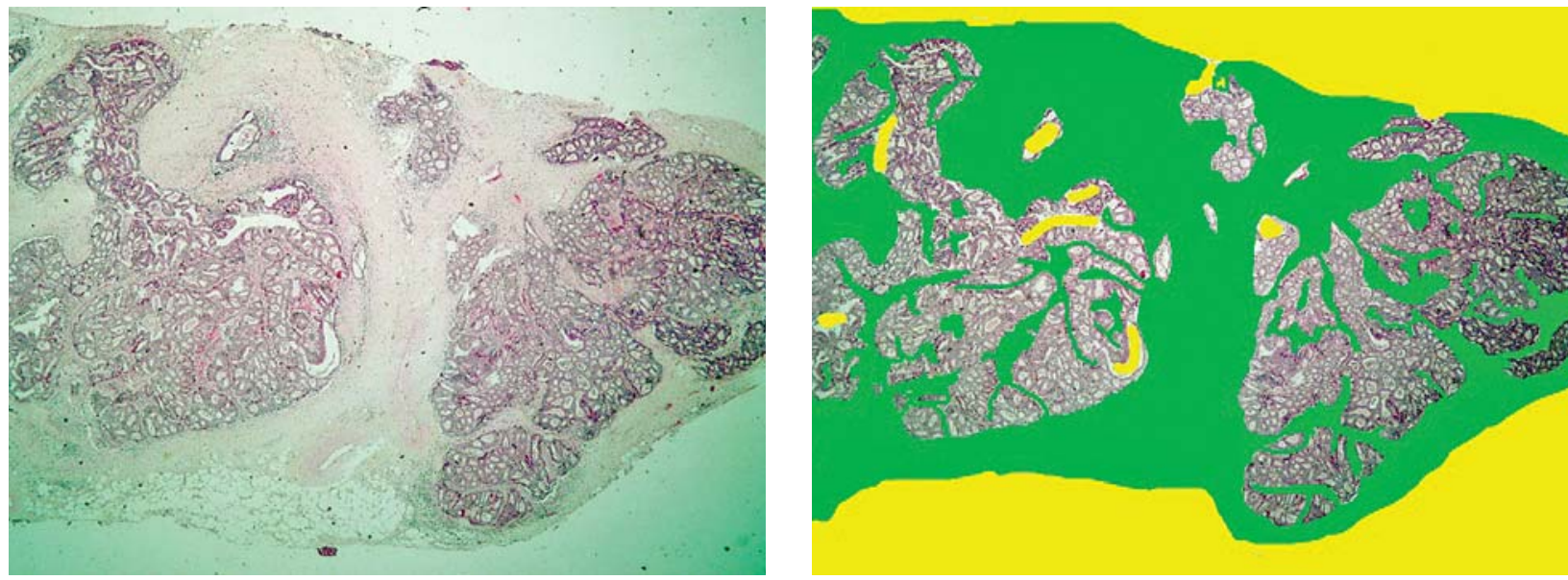

Fig. 2. Determination of stroma proportion using computer program Adobe Photoshop CS2 when tumor is not covering whole photo.

12 lymph nodes ${ }^{11}$, lymphovascular or perineural invasion, poor tumor differentiation, younger age, close resection lines, and perforation during or after surgery ${ }^{4,12}$. Based on these parameters, it is decided whether patients will receive chemotherapy.

In practice, we often encounter patients that have good prognostic factors but their metastatic disease develops very soon. Patients with a small primary tumor sometimes have a metastatic disease at the beginning.

A simple concept according to which tumor progression depends only on the intrinsic ability of tumor cells has been ever more widely rejected in the last couple of years. This points to the fact that tumor progression is the result of interaction between tumor and stroma cells, as well as the surrounding stroma cells ${ }^{13,14}$. The researches known so far have confirmed that tumor stroma influences tumor growth, angiogenesis and dissemination. It is believed that stroma induces tumorigenesis by various mechanisms such as remodeling of extracellular matrix, suppression of immune response and motility, as well as aggressiveness of cancer cells ${ }^{15-17}$.

It has been evident that stroma has a prognostic value in esophageal cancer ${ }^{18,19}$ and breast cancer ${ }^{20}$, especially triple negative breast cancer ${ }^{21,22}$.

Using simple modified methodology, we tried to determine the impact of stroma proportion on progression-free survival and overall survival. We also tried to determine the association of tumor stroma 
with previously known histopathologic features of the tumor. We tried to use simple, innovative methodology to quantifiy stroma proportion.

\section{Patients and Methods}

Our study included patients having undergone colorectal cancer surgery in 2006 and 2007 at Clinical Department of Surgery, and then treated or monitored at Clinical Department of Oncology, Osijek University Hospital Center. From analysis were excluded patients that had only colonoscopy and no surgery, and patients that died within a month after surgery (perioperative mortality). Patients that had received neoadjuvant oncologic therapy (neoadjuvant chemoradiotherapy for rectal cancer), patients with a history of malignant tumor and those with two synchronous colon cancers were not included in analysis. Considering patients having undergone surgery at Clinical Department of Surgery but not treated at Clinical Department of Oncology, Osijek University Hospital Center, only data that could be read from histopathologic findings kept at Department of Pathology, Osijek University Hospital Center were included in analysis. Department of Pathology provided data on histopathologic features of the tumor (tumor size, tumor stage, number of lymph nodes removed, number of lymph nodes with tumor cells, tumor grade of differentiation, presence of lymphovascular or perineural invasion, tumor distance from resecting edge, and whether the patient underwent surgery for metastases). Medical history of patients provided by Clinical Department of Oncology included data on patient sex and age, date of surgery, type of surgery, metastases and their locations, and adjuvant treatment of patients. We also received information on the date of disease progression, date of the last examination, and date of death for the patients that died.

Our pathologist identified the area of deepest tumor invasion with highest stroma proportion. Then he took a photo of this area at 20X magnification using Bx41 Olympus microscope with Olympus C-4040 digital camera. Using a computer program Adobe Photoshop CS2, we manually determined stroma area using green color (Fig. 1). Then we calculated the proportion of stroma based on the number of pixels (the number of green pixels/total image pixels (241968)). On most photos, tumor covered the whole photo, but
Table 1. Demographic and tumor characteristics

\begin{tabular}{|l|l|l|}
\hline \multicolumn{2}{|l|}{} & $\mathrm{n}(\%)$ \\
\hline Gender & Male & $130(55.08)$ \\
& Female & $106(44.92)$ \\
\hline Tumor site & Left & $146(71.22)$ \\
& Right & $59(28.78)$ \\
\hline T stage & T1 & $1(1.28)$ \\
& T2 & $29(12.34)$ \\
& T3 & $185(78.72)$ \\
& T4 & $18(7.66)$ \\
\hline N stage & N0 & $72(33.96)$ \\
& N1 & $56(26.42)$ \\
& N2 & $84(39.62)$ \\
\hline M stage & M0 & $163(77.62)$ \\
& M1 & $47(22.38)$ \\
\hline TNM stage & I & $22(10.43)$ \\
& II & $56(26.54)$ \\
& III & $87(41.23)$ \\
\hline Lymphovascular & IV & $46(21.80)$ \\
and perineural invasion & Yes & $59(25.11)$ \\
\hline Tumor differentiation & No & $176(74.89)$ \\
\hline Tumor stroma & Moderate & $103(50.24)$ \\
proportion & Poor & $12(43.909)$ \\
\hline & Low $(<50 \%)$ & $131(55.51)$ \\
\hline High $(>50 \%)$ & $105(44.49)$ \\
\hline
\end{tabular}

on some photos it was not possible due to the size of the tumor (Fig. 2). In this case, the number of yellow colored points was subtracted from the whole number of picture pixels. The areas of necrosis were yellow colored, while mucus that was part of the tumor was not yellow but remained colorless. Tumor stroma proportion was calculated afterwards. The cut-off point between high and low stroma proportion was set at 50\%.

\section{Statistics}

Categorical data were presented as absolute and relative frequencies. Numerical data were presented as mean and standard deviation and, if necessary, with median and quartiles and other standard measures of descriptive statistics. Analysis of variance was used to determine relationship between stroma proportion and other histopathologic characteristics. Overall survival and progression-free survival were estimated by Kaplan-Meier survival curves. Differences in overall survival and progression-free survival were tested us- 
Table 2. Relationship between overall survival and tumor characteristics

\begin{tabular}{|c|c|c|c|c|}
\hline & & $\begin{array}{l}\text { Median } \\
\text { OS/days }\end{array}$ & CI (95\%) & $p$ value $e^{\ddagger}$ \\
\hline \multirow[t]{2}{*}{ Localization } & Right & NA & 2380-NA & \multirow[t]{2}{*}{0.052} \\
\hline & Left & 1717 & $1330-2452$ & \\
\hline \multirow[t]{3}{*}{ T stage } & $\mathrm{T} 2$ & NA & NA-NA & \multirow[t]{3}{*}{0.004} \\
\hline & T3 & 1948 & $1367-2452$ & \\
\hline & $\mathrm{T} 4$ & 892 & 447-NA & \\
\hline \multirow[t]{3}{*}{$\mathrm{N}$ stage } & No & NA & 2397-NA & \multirow[t]{3}{*}{$<0.001$} \\
\hline & N1 & 2155 & 1431-NA & \\
\hline & $\mathrm{N} 2$ & 810 & $560-1408$ & \\
\hline \multirow[t]{2}{*}{ M stage } & M0 & 3287 & 2380-NA & \multirow[t]{2}{*}{$<0.001$} \\
\hline & M1 & 447 & $330-671$ & \\
\hline \multirow[t]{4}{*}{ TNM stage } & I & NA & NA-NA & \multirow[t]{4}{*}{$<0.001$} \\
\hline & II & 3287 & 2066-NA & \\
\hline & III & 2452 & 1433-NA & \\
\hline & IV & 447 & $330-671$ & \\
\hline \multirow{3}{*}{$\begin{array}{l}\text { Tumor } \\
\text { differentia- } \\
\text { tion }\end{array}$} & 1 & 2301 & 1883-NA & \multirow[t]{3}{*}{0.217} \\
\hline & 2 & 1433 & 867-NA & \\
\hline & 3 & 671 & 313-NA & \\
\hline \multirow{2}{*}{$\begin{array}{l}\text { Lympho- }^{-} \\
\text {vascular and } \\
\text { perineural } \\
\text { invasion }\end{array}$} & Yes & 1338 & 810-NA & \multirow[t]{2}{*}{0.059} \\
\hline & No & 2301 & 1431-NA & \\
\hline
\end{tabular}

$\mathrm{NA}=$ not applicable; $\mathrm{OS}=$ overall survival; ${ }^{\ddagger} \log$-rank test

ing the Cox ph model, likelihood ratio test, and logrank test. The level of significance was set at 0.05 .

On statistical analysis, was used STATISTICA64 (version 11, StatSoft.Inc., Tulsa, OK, USA) statistical program and software package R, library "OIsurv" for survival analysis ${ }^{23}$.

\section{Results}

The analysis included 236 patients with all tumor stages, mean age 64.22 (standard deviation (SD) 11.46) years. They all had undergone surgery at Cinical Department of Surgery, Osijek University Hospital Center, and 206 of them were then treated and followed up at Clinical Department of Oncology, Osijek University Hospital Center. Demographic characteristics of patients and histopathologic characteristics of tumors are shown in Table 1.
Table 3. Relationship between progression-free survival and tumor characteristics

\begin{tabular}{|c|c|c|c|c|}
\hline & & $\begin{array}{l}\text { Median } \\
\text { PFS/days }\end{array}$ & CI (95\%) & $\mathrm{p}$ value \\
\hline \multirow[t]{2}{*}{ Localization } & Right & NA & 896-NA & \multirow[t]{2}{*}{0.023} \\
\hline & Left & 715 & $583-1220$ & \\
\hline \multirow[t]{3}{*}{ T stage } & $\mathrm{T} 2$ & NA & 2553-NA & \multirow[t]{3}{*}{0.049} \\
\hline & T3 & 784 & $655-1710$ & \\
\hline & T4 & 442 & 258-NA & \\
\hline \multirow[t]{3}{*}{$\mathrm{N}$ stage } & N0 & NA & NA-NA & \multirow[t]{3}{*}{$<0.001$} \\
\hline & N1 & 1184 & 722-NA & \\
\hline & N2 & 405 & $316-595$ & \\
\hline \multirow[t]{2}{*}{$M$ stage } & M0 & 2474 & $1385-\mathrm{NA}$ & \multirow[t]{2}{*}{$<0.001$} \\
\hline & M1 & 241 & $168-334$ & \\
\hline \multirow[t]{4}{*}{ TNM stage } & I & 2553 & 2229-NA & \multirow[t]{4}{*}{$<0.001$} \\
\hline & II & NA & 1710-NA & \\
\hline & III & 1092 & 760-NA & \\
\hline & IV & 240 & 168-334 & \\
\hline \multirow{3}{*}{$\begin{array}{l}\text { Tumor } \\
\text { differentia- } \\
\text { tion }\end{array}$} & 1 & 2229 & 1092-NA & \multirow[t]{3}{*}{0.051} \\
\hline & 2 & 645 & 448-1014 & \\
\hline & 3 & 583 & 251-NA & \\
\hline \multirow{2}{*}{$\begin{array}{l}\text { Lympho- } \\
\text { vascular and } \\
\text { perineural } \\
\text { invasion }\end{array}$} & Yes & 588 & 442-1844 & \multirow[t]{2}{*}{0.029} \\
\hline & No & 1385 & 742-NA & \\
\hline
\end{tabular}

$\mathrm{NA}=$ not applicable; $\mathrm{PFS}=$ progression-free survival; ${ }^{\ddagger} \log$ rank test

We analyzed correlation between tumor stroma, pathologic characteristics of tumor and survival. Stroma proportion was determined in all study patients. The mean value of tumor stroma was $44.23 \%$ (SD $12.10 \%)$. Analysis of variance confirmed a statistically significant difference in stroma proportion due to tumor $\mathrm{T}$ stage $(\mathrm{p}=0.002)$ and $\mathrm{N}$ stage $(\mathrm{p}=0.038)$.

Relationship of the median overall survival and histopathologic characteristics of tumor is presented in Table 2. There was no statistically significant difference in overall survival according to tumor localization, tumor differentiation, and perineural and lymphovascular invasion.

Relationship between progression-free survival and tumor characteristics is presented in Table 3. There was a statistically significant difference in progression-free survival among all characteristics except for tumor differentiation.

The Cox proportional hazards methodology of modeling with a single predictor was used to analyze 


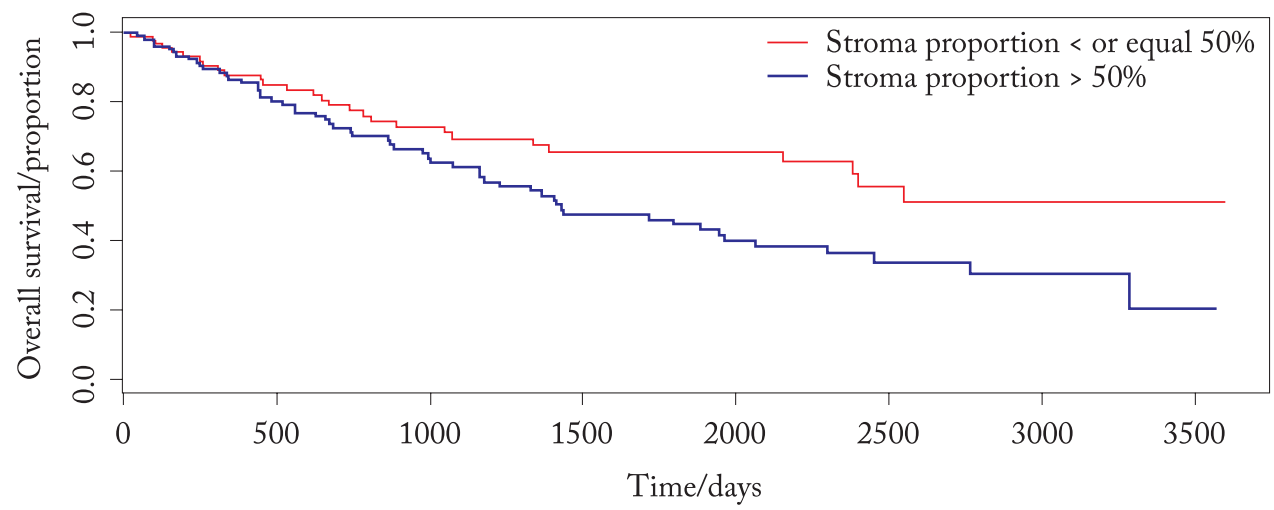

Fig. 3. Kaplan-Meier curves of overall survival and tumor stroma proportion.

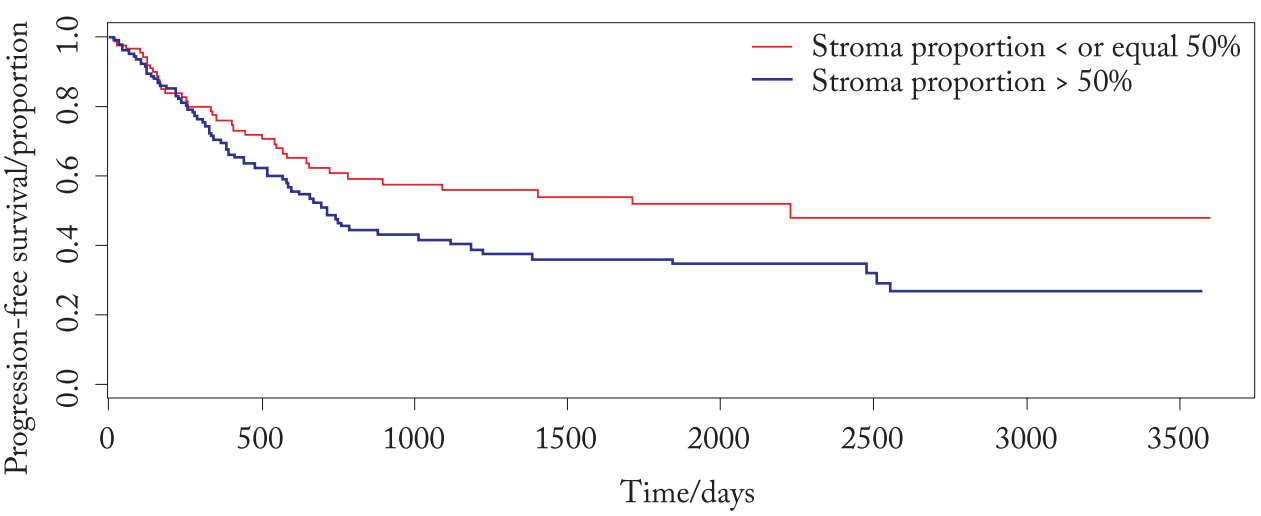

Fig. 4. Kaplan-Meier curves of progression-free survival and tumor stroma proportion.

correlation between stroma proportion and patient survival. The likelihood ratio test revealed a statistically significant role of tumor stroma proportion in the models of overall survival $(\mathrm{p}=0.016)$ and progressionfree survival $(\mathrm{p}=0.019)$.

The Kaplan-Meier survival curves of overall survival and tumor stroma proportion are shown in Figure 3, and Kaplan-Meier survival curves of progression-free survival and tumor stroma proportion in Figure 4.

\section{Discussion}

The parameters associated with worse prognosis in patients with colorectal cancer include evaluation of less than 12 lymph nodes ${ }^{10}$, lymphovascular or perineural invasion, poor tumor differentiation, younger age, close resection lines, and perforation during or after surgery ${ }^{3,11}$. These parameters are not good enough to predict outcome in patients with colorectal cancer.
We need more and better parameters in clinical practice.

In recent research, some new parameters have emerged that may have a prognostic role in colorectal cancer, one of them being the amount of stroma, which was first demonstrated as a prognostic factor in breast and esophageal cancer ${ }^{17-22}$. The role of stroma proportion, or tumor cell proportion in the prognosis of colorectal cancer has been reported in four papers so far; they have demonstrated the proportion of stroma to be a significant prognostic factor in colorectal cancer and the higher proportion of tumor stroma to be

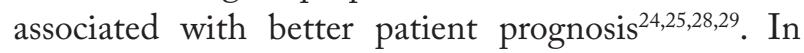
2007, Mesker et al. showed the carcinoma-stroma ratio to be an independent factor for survival as compared with lymph node status and tumor stage ${ }^{24}$. In 2010, West et al. proved the smaller cancer cell proportion to be an independent prognostic factor for survival in colorectal cancer ${ }^{25}$. In 2012, the VICTOR trial was started $^{26,27}$. The authors planned to include $7000 \mathrm{pa}^{-}$ 
tients. The purpose of this study was to test whether the COX-2 inhibitor rofecoxib could reduce recurrence and improve survival when administered in the adjuvant setting of colorectal cancer stage II and III. Since cardiotoxicity of refecoxib had been established, the trial was stopped. Results of this huge trial including over 700 patients have confirmed previous results that stroma is an independent prognostic factor in colorectal cancer stage II and $\mathrm{III}^{28}$, which was confirmed in the study conducted by Park et al. in $2014^{29}$.

Our trial confirmed difference in overall survival and progression-free survival. This difference was statistically significant, which is consistent with previous studies. Previous trials have shown strong heterogeneity in tumor cells within the tumor. The stroma proportion is not the same throughout the tumor. In breast cancer, some studies have shown that tumors with a high proportion of tumor cells at the periphery of the tumor have better prognosis ${ }^{30}$, while others report opposite findings when looking at the entire tumor $^{31}$. In previous trials, researchers used subjective methodology where two independent pathologists tried to estimate stroma proportion ${ }^{27,28}$, while Mesker et al. used a software that is not available in every hos$\mathrm{pital}^{24}$. In our trial, we tried to quantify stroma proportion using a simple, widely accessible methodology. Using this methodology, it is simple to determine stroma proportion. According to previous trials $\mathrm{s}^{24,25,28,29}$ and the fact that it is impossible to determine stroma proportion in the whole tumor, we believe that the area with the largest stroma proportion at the site with deepest tumor penetration is adequate to analyze and set the stroma proportion as a prognostic factor for colorectal cancer.

In conclusion, our study showed the importance of tumor stroma proportion in determining outcome in patients with colorectal cancer. As it is simple to determine, it could be included as a prognostic parameter in the routine histopathologic reports.

\section{References}

1. Hrvatski zavod za javno zdravstvo. Registar za rak Republike Hrvatske. Incidencija raka u Hrvatskoj 2013., Bilten 38, Zagreb, 2015. (in Croatian)

2. Tripković I, Strnad M, Polić Vižintin M, Mulić R, Tripković I. Colorectal cancer in Split-Dalmatia County. Acta Clin Croat. 2009 Sep;48(4):423-6.
3. Wishner JD, Baker JW Jr, Hoffman GC, Hubbard GW $2^{\text {nd }}$, Gould RJ, et al. Laparoscopic-assisted colectomy. The learning curve. Surg Endosc. 1995;9(11):1179-83.

4. National Comprehensive Cancer Network. Guideliness for treating cancer by site, version 2.2016.

5. Des Guetz G, Uzzan B, Morere JF, Perret G, Nicolas P. Duration of adjuvant chemotherapy for patients with non-metastatic colorectal cancer. Cochrane Database Syst Rev. 2010 Jan 20;(1):CD007046. doi: 10.1002/14651858.CD007046.pub2

6. Gray R, Barnewell J, McConkey C, et al. Adjuvant therapy versus observation in patients with colorectal cancer: a randomised study. Lancet 2007;370:2020-9. doi: 10.1016/S0140-6736(07) 61866-2

7. Efficacy of adjuvant fluorouracil and folinic acid in colon cancer. International Multicentre Pooled Analysis of Colon Cancer Trials (IMPACT) investigators. Lancet. 1995 Apr 15;345 (8955):939-44.

8. Efficacy of adjuvant fluorouracil and folinic acid in B2 colon cancer. International Multicentre Pooled Analysis of B2 Colon Cancer Trials (IMPACT B2) investigators. J Clin Oncol. 1999 May;17(5):1356-63.

9. Hanna NN, Onukwugha E, Choti MA, et al. Comparative analysis of various prognostic nodal factors, adjuvant chemotherapy and survival among stage III colon cancer patients over 65 years: an analysis using surveillance, epidemiology and end results (SEER) - Medicare data. Colorectal Dis. 2012 Jan; 14(1):48-55. doi: 10.1111/j.1463-1318.2011.02545.x

10. Wu X, Zhang J, He X, Wang C, Lian L, et al. Postoperative adjuvant chemotherapy for stage II colorectal cancer: a systematic review of 12 randomized controlled trials. J Gastrointest Surg. 2012 Mar;16(3):646-55. doi: 10.1007/s11605-011-1682-8. Epub 2011 Dec 23

11. Nedrebø BS, Søreide K, Nesbakken A, et al. Risk factors associated with poor lymph node harvest after colon cancer surgery in a national cohort. Colorectal Dis. 2013;15(6):e301-8. doi: 10.1111/codi.12245

12. Lykke J, Rojkjaer O, Jess P; Danish Colorectal Cancer Group. The relation between lymph node status and survival in stage I-III colon cancer: results from a prospective nationwide cohort study. Colorectal Dis. 2013 May;15(5):559-65. doi: 10.1111/ codi.12059

13. Colotta F, Allavena P, Sica A, Garlanda C, Mantovani A. Cancer-related inflammation, the seventh hallmark of cancer: links to genetic instability. Carcinogenesis. 2009;30(7):1073-81. doi: 10.1093/carcin/bgp127. Epub 2009 May 25

14. Hanahan D, Weinberg RA. Hallmarks of cancer: the next generation. Cell. 2011;144(5):646-74. doi: 10.1016/j.cell.2011. 02.013

15. Kim JB, Stein R, O'Hare MJ. Tumour-stromal interactions in breast cancer: the role of stroma in tumourigenesis. Tumor Biol. 2005;26(4):173-85. doi:10.1159/000086950

16. Hu M, Polyak K. Microenvironmental regulation of cancer development. Curr Opin Genet.2008;18(1):27-34. doi: 10.1016/j. gde.2007.12.006. Epub 2008 Feb 20 
17. Cirri P, Chiarugi P. Cancer-associated fibroblasts and tumour cells: a diabolic liaison driving cancer progression. Cancer $\mathrm{Me}-$ tastasis Rev. 2012;31(1-2):195-208. doi: 10.1007/s10555-0119340-x

18. Wang K, Ma W, Wang J, Yu L, Zhang X, et al. Tumor-stroma ratio is an independent predictor for survival in esophageal squamous cell carcinoma. J Thorac Oncol. 2012;7(9):1457-61. doi: 10.1097/JTO.0b013e318260dfe8

19. Courrech Staal EF, Wouters MW, van Sandick JW, Takkenberg MM, Smit VT, et al. The stromal part of adenocarcinomas of the oesophagus: does it conceal targets for therapy? Eur J Cancer. 2010;46(4):720-8. doi: 10.1016/j.ejca.2009.12.006. Epub 2010 Jan 13

20. Gujam FA, Edwards J, Mohammed MA, Going JJ, McMillan DC. The relationship between the tumour stroma percentage, clinicopathological characteristics and outcome in patients with operable ductal breast cancer. Br J Cancer. 2014;111: 157-65. doi: 10.1038/bjc.2014.279. Epub 2014 May 29

21. de Kruijf EM, van Nes JG, Van de Velde CJ, Putter H, Smit VT, et al. Tumor-stroma ratio in the primary tumor is a prognostic factor in early breast cancer patients, especially in triplenegative carcinoma patients. Breast Cancer Res Treat. 2011; 125(3):687-96. doi: 10.1007/s10549-010-0855-6. Epub 2010 Apr 2

22. Moorman AM, Vink R, Heijmans HJ, van der Palen J, Kouwenhoven EA. The prognostic value of tumour-stroma ratio in triple-negative breast cancer. EurJ Surg Oncol.2012;38(4):30713. doi: 10.1016/j.ejso.2012.01.002. Epub 2012 Jan 20

23. Diez DM. Package "OIsurv". https://cran.r-project.org/web/ packages/OIsurv/OIsurv.pdf (23.11.2016)

24. Mesker WE, Junggeburt JM, Szuhai K, de Heer P, Morreau H, Tanke HJ, Tollenaar RA. The carcinoma-stromal ratio of colon carcinoma is an independent factor for survival compared to lymph node status and tumor stage. Cell Oncol. 2007;29(5): 387-98.

25. West NP, Dattani M, McShane P, Hutchins G, Grabsch J, et al. The proportion of tumour cells is an independent predictor for survival in colorectal cancer patients. Br J Cancer. 2010;102 (10):1519-23. doi: 10.1038/sj.bjc.6605674 Epub 2010 Apr 20

26. Midgley RS, McConkey CC, Johnstone EC, et al. Phase III randomized trial assessing rofecoxib in the adjuvant setting of colorectal cancer: final results of VICTOR trial. J Clin Oncol. 2010;28:4575-80. doi: 0.1200/JCO.2010.29.6244. Epub 2010 Sep 13

27. Pendlebury S, Duchesne F, Reed KA, et al. A trial adjuvant therapy in colorectal cancer: the VICTOR trial. Clin Colorectal Cancer. 2003;3:58-60. doi: 10.3816/CCC.2003.n.013

28. Huijbers A, Tollenaar RA, Pelt GW, Zeestraten EC, Dutton S, et al. The proportion of tumor-stroma as a strong prognosticator for stage II and III colon cancer patients: validation in the VICTOR trial. Ann Oncol. 2013;24(1):179-85. doi: 10.1093/ annonc/mds246. Epub 2012 Aug 2

29. Park J, Richards C, McMillan D, Horgan P, Roxburgh C. The relationship between tumour stroma percentage, the tumour microenvironment and survival in patients with primary operable colorectal cancer. Ann Oncol. 2014;25(3):644-51. doi: 10.1093/annonc/mdt593. Epub 2014 Jan 23

30. Baak JP, Van Dop H, Kurver PH, Hermans J. The value of morphometry to classic prognosticators in breast cancer. Cancer. 1985 Jul 15;56(2):374-82.

31. Tanaka K, Yamamoto D, Yamada M, Okugawa H. Influence of cellularity in human breast carcinoma. Breast. 2004 Aug;13 (4):334-40. doi:10.1016/j.breast.2004.02.002

Sažetak

\title{
UDIO TURMOSKE STROME KAO LOŠ PROGNOSTIČKI ČIMBENIK KOD KARCINOMA DEBELOG CRIJEVA
}

\author{
J. Flam, D. Gugić, M. Benšić, S. Tomić i J. Rajc
}

Dokazano je da je visok udio strome značajan prognostički čimbenik kod karcinoma jednjaka i karcinoma dojke. Prethodna istraživanja su pokazala da bi isti utjecaj stroma mogla imati i kod kolorektalnog karcinoma. Cilj istraživanja je bio utvrditi je li udio tumorske strome povezan s preživljenjem bolesnika s kolorektalnim karcinomom. Provedeno je retrospektivno istraživanje u 236 bolesnika koji su operirani na Klinici za kirurgiju Kliničkoga bolničkog centra Osijek. Određeno je područje s najvećim udjelom strome u području najdubljeg prodora tumora. Bolesnici su podijeljeni u dvije skupine: onu s visokim udjelom strome $(>50 \%)$ i onu s niskim udjelom strome $(\leq 50 \%)$. Udio tumorske strome bio je statistički značajno povezan sa stadijem tumora. Kaplan-Meierova analiza je pokazala statistički značajnu razliku u ukupnom preživljenju (Cox ph model p=0,016) i preživljenju do progresije (Cox ph model, $\mathrm{p}=0,0188$ ) bolesnika u odnosu na udio strome. Rezultati su pokazali statistički značajno kraće ukupno preživljenje i preživljenje do progresije bolesti kod bolesnika s visokim udjelom strome.

Ključne riječi: Kolorektalni tumori; Stromalne stanice; Preživljavanje; Bolest, napredovanje; Preživljavanje bez znakova bolesti; Prognoza 